\title{
THE NON-OBVIOUSNESS REQUIREMENT IN THE CHILEAN PATENT LAW: A CRITICAL ASSESSMENT**
}

\author{
EL REQUISITO DE LA NO OBVIEDAD EN EL DERECHO DE \\ PATENTES CHILENO: UNA VALORACIÓN CRÍTICA
}

\author{
Fernando Fernández**
}

\begin{abstract}
The conventional rationale for granting patent protection is based upon the belief that patents are an important element in order to incentivize technological and productive innovation. The patent system sets out a series of requirements that inventions must meet. These conditions on patentability purport to ensure that patents serve as a real incentive -and not an obstacle- for innovation. The patent regime thus protects inventions that, in general, are useful, new, and non-obvious in light of the prior art. Improper application of these requirements, however, has created a dilemma for patent law. In particular, the PTO has issued myriad IP rights of dubious validity. This problem seems to be particularly acute in the case of the nonobviousness condition. Indeed, both academics and judges have struggled to identify a principled method for assessing whether claimed inventions meet this requirement. This paper seeks to critically analyze the criteria set out by the Chilean Patent Office in order to estimate whether a certain invention is indeed nonobvious.
\end{abstract}

Key words: Industrial Property Law, Patent Law, Non-obviousness, Inventive Step, Innovation, Chile.

RESUMEN: La racionalidad convencional para otorgar la protección de patentes está basada en la creencia de que las patentes son un elemento importante para incentivar la innovación tecnológica y productiva. El sistema de patentes establece una serie de requisitos que las invenciones deben cubrir. Estas condiciones de patentabilidad intentan asegurar que las patentes sirvan como un incentivo real -y no un obstáculo- para la innovación. El régimen de patentes protege inventos que, en general, son útiles, nuevos y no obvios a la luz del arte previo. La aplicación impropia de estos requisitos, no obstante, ha creado un dilema para el Derecho de patentes. En particular, se han otorgado innumerables derechos de propiedad industrial de dudosa validez. Este problema parece ser particularmente agudo en el caso de la condición de no obviedad. Efectivamente, tanto académicos como jueces han batallado para identificar un método basado en principios que les permita valorar si una invención cubre este requisito. Este trabajo busca analizar críticamente el criterio establecido por el INAPI para estimar si cierta invención es o no obvia.

Palabras clave: Ley de Propiedad Industrial, Derecho de Propiedad Industrial, No obviedad, Nivel Inventivo, innovación, Chile.

\footnotetext{
* This paper is the winner of the $2011 \mathrm{RChD}$ award, in the area of commerial law.

** Lawyer, LLB. Diego Portales University, LLM. University of Chicago, LLM, University of Edinburgh. E-mail: ffernandez@sateler.cl
} 


\section{INTRODUCTION}

Thanks to the seminal work of such economists as Joseph Schumpeter and Robert Solow, ${ }^{1}$ nowadays there is a consensus that innovation is a key engine for economical development and wealth creation. Indeed, the process of technological improvement has relevance to several areas of human development, including competitiveness of business and economies, participation in global markets and production networks, and the quality of life of citizens. ${ }^{2}$

Within that framework, there is a conventional understanding that the patent system's purpose is to encourage innovation. ${ }^{3}$ In order to reach that outcome, the law seeks to balance the occasionally inconsistent interests of patent holders, follow-on inventors, and consumers. It does so by setting out a series of limitations on patent protection. ${ }^{4}$

One of these limitations is the "nonobviousness" requirement, which is, according to some scholars, the "the ultimate condition of patentability". 5 According to article 35 the Industrial Property Act ${ }^{6}$ (hereinafter, "IPA") an invention is nonobvious "if it is neither obvious to a person of average skill in the art nor obviously derived from the state of the art."

The assessment of this requirement seems to be rather problematic. As DURIE and LEMLEY note, ${ }^{7}$ the nonobviousness condition is "...perhaps the most vexing doctrine to apply, in significant part because the ultimate question of obviousness has an "I know it when I see it" quality that is hard to break down into objective elements" ${ }^{8}$

\footnotetext{
1 See Solow (1956) pp. 65-94, SOLOW (1957) pp. 312-320.

2 ORGANIZATION FOR ECONOMIC CO-OPERATION AND DEVELOPMENT (2008) p. 2.

3 Indeed, this approach seems to be the predominant vision within the intellectual property laws at international level and within Western legal regimes. See for instance: (1) at international level, article 7 of the Agreement on Trade-Related Aspects of Intellectual Property Rights, Apr. 15, 1994, Marrakesh Agreement Establishing the World Trade Organization, Annex 1C, 1869 U.N.T.S. 299 (1994) (hereinafter, "TRIPS Agreement"); (2) Within the United States of America, article I, section 8, paragraph 8 of the U.S. Constitution and; (3) within the European Community, recital 5 of the European Commission Regulation (EC) No 772/2004 of 27 April 2004 on the application of Article 81(3) of the Treaty to categories of technology transfer agreements, L 123 O.J., 27.4.2004, pp. 11-17. (Hereinafter “TTBER") and paragraphs 7 and 9 of the Guidelines on the application of Article 81 of the EC Treaty to technology transfer agreements. C 101 O.J., 27.4.2004, pp. 2-42. (Hereinafter “TTG”)

${ }^{4}$ It is above the scope of this paper discussing other requirements and limitations of patent laws. Nevertheless, the reader should be aware about those that are common among different jurisdictions. These includes, inter alia, the existence of a limited time of protection (20 years from the moment that the patentee start the registration process), that invention must be novel (novelty) and have to be useful (utility), the patent have to disclose the invention and to contain a written description of the invention clearly enough to enable any person skilled in the art to make and use it (disclosure and enablement), be an invention that follow within the patentable subject matter of the corresponding patent legislation, etc.

${ }_{6}^{5}$ Durie and Lemley (2008) p. 990.

${ }^{6}$ Ministry of the Economy Law-Ranking Decree No. 3 of 20 June 2006 establishing the consolidated, coordinated and systematized text of Law No. 19.039 on Industrial Property, published in the official gazette on June 26, 2006.

7 Of course Durie and Lemley have in mind the nonobviousness requirement set out in the U.S. Law (35 U.S.C. 103). Still, since article 35 of the IPA resembles to $\$ 103$ of the U.S. Patent Act, we think that the comment is equally pertinent for the nonobviousness requirement in the Chilean case.

8 Durie and Lemley (2008) p. 990.
} 
Despite the key role that this requirement plays in the patent system, and the difficulty of assessing it, Chilean scholars have never analysed this requirement in depth. In other words, there is no critical analysis about the way the Chilean Patent Office 9 (hereinafter, the "CPO") should evaluate this legal requirement.

This lack of scholarly discussion invites us to visit this problem by critically analysing the criteria set out within the CPO in order to determine whether a certain innovation is obvious. Furthermore, apart from researching a legal field that has been literally unexplored in Chile, it is possible to affirm that this research will allow at least three further things: (1) to put Chilean public institutions in a better position to design more effective innovation policies; (2) to increase the existing information for the actors involved in the innovation process in order to maximise the benefits of patent law; and (3) increase legal certainty in relation to the interpretation of the Chilean Industrial Property Act.

In doing so, this analysis will entail a comparative assessment of the approaches taken by innovation-based economies such as the United States and certain European countries.

Part (I) of this paper will briefly address the economic rationale of the patent system generally and the "nonobviousness" requirement in particular. Then, Part (II) will briefly summarize the criteria set out in the U.S. and Europe to assess this requirement. Part (III) shall provide a general background of the nonobviousness requirement within the Chilean patent law. Part (IV) will analyze the principles used by the CPO in order to assess whether an invention is obvious. Finally, Part (V) will provide some normative suggestions that the CPO should consider.

\section{THE ECONOMIC RATIONALE OF PATENT LAW AND THE “NON- OBVIOUSNESS" REQUIREMENT}

Patents seek to incentivize innovation by preventing free riders from copying certain inventions. LANDES and POSNER summarize the economic rationale of patent rights as follows:

"The conventional rationale for granting legal protection to inventions as to expressive works is the difficulty that a producer may encounter in trying to recover his fixed costs of research and development when the product or process that embodies a new invention is readily copiable. A new product, for example, may require the developer to incur heavy costs before any commercial application can be implemented, so that a competitor able to copy the product without incurring

\footnotetext{
9 To be more precise, the registration process of a patent is done before the Patent Department of the Instituto Nacional de Propiedad Industrial (National Institute of Industrial Property). This department is the equivalent of a patent office so, for the sake of simplicity, we shall refer as the "Chilean Patent Office".

However, the reader should be aware that the Instituto Nacional de Propiedad Industrial is also on charge of the registration process of trademark, industrial design rights, utility models, plants varieties, etc.
} 
those costs will have a cost advantage that may lead to a fall in the market price to a point at which the developer cannot recover his fixed costs." 10

In other words, without patent protection, competitors would be able to imitate such inventions, driving down prices and preventing inventors from recovering their costs and profiting from their creations. Consequently, the inventor would lack incentives to invest time and money in order to create further innovations. ${ }^{11}$

Related to the latter rationale, the existing literature agrees that patents are necessary to induce inventors to disclose their inventions instead of keeping them in secret. ${ }^{12}$ This function is achieved by requiring patent applicants to disclose the invention in a clear and complete manner so as to enable any person skilled in the art to recreate and use it. ${ }^{13}$ The most important benefit of the disclosure function ${ }^{14}$ is the dissemination of knowledge, providing other inventors with new ideas to produce further inventions, ${ }^{15}$ in particular, "... where secrecy can be effective in enabling an inventor to reap at least some returns". ${ }^{16}$ This feature of the patent system provides two useful by-products: (1) the disclosure function of patent laws allows competing innovators "...to "invent around" the patented invention that is, to achieve the technological benefits of the patent without duplicating the particular steps constituting it and thus without infringement". ${ }^{17}$ Consequently, this requirement, plus the fact that the scope of the patent is restricted to a specific technical solution (rather than a type of utility or function), facilitates competitive innovation of alternative technical solutions; ${ }^{18}$ (2) minimises (although not eliminates) the existence of patent races since patents "...not only disclose how to make and use the claimed invention, but also notify the public of the patentee's exclusive rights to that technology" ${ }^{19}$ By minimizing patent races, in theory, this feature of the patent system mitigate duplicative expenditure in innovation that, eventually, might surpass the social benefits obtained by the invention ${ }^{20}$.

\footnotetext{
10 LANDEs (2003) p. 294.

11 In the same sense, see "The disclosure function of the Patent System (or lack thereof)", Harvard Law Review, Vol. 118, issue 6, 2005, pp. 2008-2009. See also Mazzoleni and Nelson (1998) p. 1035.

12 Mazzoleni and Nelson (1998) pp. 1038-1039; Machlup and Penrose (1950) p. 25; Cornish and LLeWelyn (2003) paras. 3.49 - 3-51; LAndes \& Posner (2003) pp. 329-330.

Yet, contrast the general opinion with DevLIN (2010) p. 4 ("disclosure should be treated merely as an ancillary feature of the patent system")

${ }^{13}$ For instance, paragraph 3, article 43bis of the IPA states that " $\left.\mathrm{t}\right]$ he description shall be clear and complete, so as to enable an expert in such matters to reproduce the invention without the need for other information".

${ }^{14}$ For other benefits, see 'The disclosure function of the Patent System (or lack thereof)'(2005) p. 2010.

15 'The disclosure function of the Patent System (or lack thereof)' (2005) p. 2010.

In this sense, the TRIPS Agreement in Art. 7 remarks the importance of IPRs for "...the transfer and dissemination of technology...”.

${ }^{16}$ Mazzoleni and Nelson (1998) pp. 1038-1039. According to the same authors, this happens in many processes inventions.

17 Landes and Posner (2003) p. 295.

18 GHidini (2006) p. 7.

19 'The disclosure function of the Patent System (or lack thereof)'(2005).

${ }^{20}$ Still, patent races are not entirely undesirable. Indeed, patent races also incentivize some desirable features. As noted by Judd, Schmedders and Yeltekin patent races serves also for some desirable purposes: "races of
} 
However, the creation of exclusive rights in public goods ${ }^{21}$ (such as ideas) also imposes certain social costs. Patents allow patent holders to charge monopoly prices for using the patented idea, which in turn increases third parties' cost of accessing such information. This appropriation of ideas and technical and scientific information generates an artificial scarcity of raw material for follow-on innovators in order to create new inventions. If such appropriation were absolute and over expansive, a patent could constitute a barrier (rather than an incentive) to innovation. ${ }^{22}$

Apart from the disclosure function underlined above, patent law has a series of tools with which to tackle these costs. One of them is the "nonobviousness" requirement. The economic underpinnings of this prerequisite to patentability lie upon the fact that it excludes from patent protection those innovations that could be discoverable by using other incentives, such as first-mover advantage or strong competition social costs than granting a patent. In words of KICHT:

"The non-obviousness test shares the economic premises of both the novelty and genius tests $\left[{ }^{23}\right]$. With the novelty test it shares that innovation should be encouraged. With the genius test it shares the premise that patent monopolies represent a substantial cost to the consumer. These two premises are accommodated by the basic principle on which the non-obviousness test is based: a patent should not be granted for an innovation unless the innovation would have been unlikely to have been developed absent the prospect of a patent. [...] The non-obviousness test makes an effort, necessarily an awkward one, to sort out those innovations that would not be developed absent a patent system. Through the years the test has been variously phrased, but the focus has always been on the question whether the

nontrivial duration are part of an optimal policy under most circumstances. In our setting, the patent race serves two purposes. First, it motivates the firms to invest and complete the innovation process quickly. When the prize causes inefficiencies, such as the monopoly grant implicit in a patent, using a race allows the planner to reduce the size of the prize and still give firms incentives to invest in innovation. Second, a race filters out inferior innovators since they cannot keep up with the more efficient ones." Judd, Schmedders and YELTEKIN (2010) p. 30.

Furthermore, as LANDEs and Posner, notes, the social loss of a patent race has to be taken with some qualifications: (1) loser's research costs might not be entirely wasted and could be used for other projects and (2) "patent races need not produce any social waste at all in cases" (they put as an example the pharmaceutical industry in which the patent race might lead to different patents) See Landes and Posner (2003) pp. 301302.

21 Public goods are goods that “...can be consumed without reducing any other person's consumption of it" POSNER (2007) p. 41.

22 Cotropia \& Gibson (2010) p. 923. In the same sense see Joseph Stiglitz:

"[...] intellectual property attempts to restrict the use of knowledge in one way or another. Intellectual property is supposed to encourage innovation. I argue below that a poorly designed intellectual property regime one that creates excessively "strong" intellectual property rights can actually impede innovation."

STIGLitz (2007) p. 1696.

23 The reader should note that the "genius test" currently does apply neither to U.S. Law nor to Chilean Patent Law. For the American case, see Kiтch (1966) pp. 300 and 301. 
innovation could have been achieved by one of ordinary skill in the art, or whether its achievement is of a greater degree of difficult" ${ }^{24}$

Furthermore, this requirement minimizes the impact of patent races. As DAM has summarized, "[b]ecause [the non-obviousness] requirement eliminates patents on low-contribution discoveries, it thereby eliminates one form of competition [(i.e., patent races)] that may be considered wasteful. After all, a patent on something obvious may nonetheless be worth a great deal due to the power to exclude others. And the very obviousness of the invention may lead a correspondingly large number of inventors to seek the prize of a patent." 25 Therefore, this requirement impedes the exacerbation of the deadweight loss that rent seeking inflicts on society as a whole. In the words of EISENBERG:

"[...] the point of the nonobviousness requirement is to distinguish patentworthy inventions from routine advances that do not require the incentive of a patent, [...] is a sensible frame of reference. An invention that seems obvious at the time it was made to ordinary practitioners in the technological community is likely to occur promptly to others with or without the inventor's efforts, and the legislative choice to exclude such slight advances from patent protection seems to be a reasonable rule of thumb. Otherwise, consumers would endure unnecessary restrictions on competition in new technologies and competitors would feel compelled to waste resources racing to make and patent modest incremental advances for fear of being foreclosed by the patents of others from doing what comes easily to their own scientists and engineers." 26

Finally, the nonobviousness test serves "a gatekeeping function" to incentivize uncertain innovations. As noted by MERGES:

"[nonobviousness] influences behavior-specifically, the decisions of research and development $(\mathrm{R} \& \mathrm{D})$ managers to pursue or ignore specific research projects. The nonobviousness standard encourages researchers to pursue projects whose success appears highly uncertain at the outset. The standard insists that only the results from uncertain research should be rewarded with a patent." 27

In sum, the nonobviousness requirement serves as a pro-competitive standard which (1) incentivizes innovations that would be unlikely without giving the chance to charge monopoly prices to recuperate the costs of research and development (hereinafter, "R\&D"), (2) minimizes the impact of rent seeking of low-contribution discoveries and

\footnotetext{
24 Кітсн (1966) pp. 300 and 301.

25 DAM (1994) p. 264 (footnotes omitted)

${ }^{26}$ Esienberg (2004) pp. 886-887.

27 Merges (1992) p. 2. See also Merges and Duffy (2007) pp. 695-703.
} 
(3) encourages people to spend resources in $\mathrm{R} \& \mathrm{D}$ with uncertain results. Consequently, this allows knowledge created by incremental innovations to become part of the public domain, letting third parties (including competitors) use this knowledge in order to pursue further innovation.

As noted above, despite the importance and utility of this requirement, there is some consensus that the determination of this requirement is rather elusive. ${ }^{28}$ Now we shall briefly explore the analytical tools crafted by the United States Patent and Trademark Office (hereinafter, the "USTPO") and European Patent Office (hereinafter, the "EPO") in order to evaluate this requirement.

\section{THE "NONOBVIOUSNESS" / "INVENTIVE STEP" REQUIREMENT IN THE U.S. AND EUROPE.}

The "nonobviousness" / "inventive step" requirement is an international standard set out in article 27(1) of the TRIPS Agreement. This provision states, in relevant part, the following:

\section{"Article 27 Patentable Subject Matter}

1. Subject to the provisions of paragraphs 2 and 3, patents shall be available for any inventions, whether products or processes, in all fields of technology, provided that they are new, involve an inventive step and are capable of industrial application. ${ }^{(5)}$

(5) For the purposes of this Article, the terms "inventive step" and "capable of industrial application" may be deemed by a Member to be synonymous with the terms "non-obvious" and "useful" respectively"

Although this provision binds World Trade Organization's members to implement such standard, the TRIPS Agreement provides no guidance whatsoever on how implement it. On the contrary, "TRIPS leaves the height of the inventive step to national law". ${ }^{29}$ Unsurprisingly, there is a divergence of the criterion applied by patent offices and courts around the world in how to measure said test.

Chile is not the exception. However, the CPO in establishing their own standards for evaluating the nonobviousness requirement used the criteria used by USTPO and EPO as a model. This leads us to examine both regimes to then examine, in the next chapter, the CPO's "nonobviousness" Guidelines.

\footnotetext{
${ }^{28}$ It is above the scope of this paper to discuss such matter. For those interested in studying this discussion in the U.S. see, inter alia, BARTON (2003) pp. 475-508; DURIE and LemLey (2008) pp. 989-1020; Esienberg (2004) pp. 886-887. In the case of Europe see, inter alia, Pagenberg (1978) pp. 121-152; Franzosi (2003) pp. 233-250.

29 Reichman and Dreyfuss (2007) p. 99.
} 


\subsection{The U.S. LAW}

The USTPO sets out its criterion of patentability in Chapter 2100 Manual of Patent Examining Procedure (hereinafter, the "MPEP"). ${ }^{30}$ These guidelines are intended to provide guidance to patent examiners to determine the obviousness standard set out in 35 U.S.C. 103 taking into consideration the U.S. case law ${ }^{31}$. In 2007, this chapter it was updated in order to take into account the Supreme Court's decision in KSR International. ${ }^{32}$ The latter ruling reaffirmed the three-step factual inquiry suggested in Graham. In this regard, the MPEP, paraphrasing Graham" ${ }^{33}$, come to state that "[o] bviousness is a question of law based on underlying factual inquiries". ${ }^{34}$ These factual inquiries the following: "(A) Determining the Scope and Content of the Prior Art; (B) Ascertaining the differences between the claimed invention and the prior art; and $(\mathrm{C})$ Resolving the level of ordinary skill in the pertinent art." 35 Now we shall pass to enunciate the criterion used by the MPEP to answer each enquiry.

\subsubsection{The Graham enquiry}

(a) First: Determination the Scope and Content of the Prior Art. In order to identify such differences, examiners are asked first to define the scope and content of the prior art. In order to do so, the examiner has to understand what is disclosed and claimed in the application, giving the patent claims the "broadest reasonable interpretation consistent with the specification."36, 37

Having determined the scope of the invention, the examiner has to determine where and what to search for. In this regard, the search will cover "the claimed subject matter and $[\ldots]$ the disclosed features which might reasonably be expected to be claimed”.38

Then, the examiner will determine which is the "prior art". In general terms, "prior art" will be all the references that have become part of the art before the date of the filling of the application. ${ }^{39}$ For the purposes of defining what the prior art is, the MPEP will consider the prior art found at the moment of doing the $\$ 102$ exam (i.e., novelty,

\footnotetext{
${ }^{30}$ UNITED STATES PATENT AND TRADEMARK OFFICE (2001).

31 Notably, Graham v. John Deere Co., 383 U.S. 1; 148 USPQ 459 (1966) (hereinafter, "Graham"); KSR International Co. v. Telflex Inc., 550 U.S. 398 (2007); 82 USPQ2d 1385 (2007); 2007 U.S. LEXIS 4745 (April 30, 2007) (hereinafter, "KSR International")

32 UNITED STATES PATENT AND TRADEMARK OFFICE (2001), Chapter 2100, paragraph 2141, pp. 115-116.

33383 U.S. 1, p. 17.

${ }^{34}$ UNITED STATES PATENT AND TRADEMARK OFFICE (2001), Chapter 2100, paragraph 2141, p. 116.

35 UNITED STATES PATENT AND TRADEMARK OFFICE (2001), Chapter 2100, paragraph 2141, p. 116.

36 UNITED STATES PATENT AND TRADEMARK OFFICE (2001), Chapter 2100, paragraph 2141, p. 117.

37 Contrast this approach with the EPO Guidelines.

38 UNITED STATES PATENT AND TRADEMARK OFFICE (2001), Chapter 2100, paragraph 2141, p. 117.

39 See Merges and Duffy (2007) p. 360.
} 
derivation and statutory bar). ${ }^{40,41}$ However, taking note from the U.S. Supreme's ruling in KSR International, the MPEP makes clear that "for purposes of 35 U.S.C. 103, prior art can be either in the field of applicant's endeavor or be reasonably pertinent to the particular problem with which the applicant was concerned. Furthermore, prior art that is in a field of endeavor other than that of the applicant [...], or solves a problem which is different from that which the applicant was trying to solve, may also be considered for the purposes of 35 U.S.C. 103.” 42

(b) Second: Ascertaining the differences between the claimed invention and the prior art. According to the MPEP, this step basically "requires interpreting the claim language [...] and considering both the invention and the prior art as a whole." 43

(c) Third: Resolving the Level of Ordinary Skill in the Art. According to the MPEP, this determination will basically be based upon the following factors: "(1) "type of problems encountered in the art;" (2) "prior art solutions to those problems;" (3) "rapidity with which innovations are made;" (4) "sophistication of the technology; and" (5) "educational level of active workers in the field. In a given case, every factor may not be present, and one or more factors may predominate."” 44

Furthermore, considering the KSR International ruling, the MPEP will consider that the person with of ordinary skill in the art is a person with ordinary creativity and able to "fit the teachings of multiple patents together like pieces of a puzzle." 45

Finally, in order to avoid hindsight bias problems, the Federal Circuit's case law have make clear that the level of ordinary skill in the art is determined at the moment that "the invention was made" 46 and not at the moment that the nonobviousness analysis takes place.

\footnotetext{
40 See 35 U.S.C. 102. For further detail and comment upon this matter, see also Merges and Duffy (2007) pp. 357 et seq.

${ }^{41}$ In this regard, see UNITED STATES PATENT AND TRADEMARK OFFICE (2001) $\$ 904$ to $\$ 904.03$. For case law and comments regarding this matter, see also, Merges and Duffy (2007) pp. 357 et seq.

The reader should note that the use of $\$ 102(\mathrm{e})$ and $(\mathrm{g})$ prior art is subject from some qualifications. See Merges and Duffy (2007) pp. 742, discussing In re Bass, 474 F.2d 1276 (C.C.P.A. 1973).

42 UNITED STATES PATENT AND TRADEMARK OFFICE (2001), Chapter 2100, paragraph 2141, p. 117.

${ }^{43}$ UNITED STATES PATENT AND TRADEMARK OFFICE (2001), Chapter 2100, paragraph 2141, pp. $117-118$.

${ }^{44}$ UNITED STATES PATENT AND TRADEMARK OFFICE (2001), Chapter 2100, paragraph 2141, pp. 118, citing the following cases: In re GPAC, 57 F.3d 1573, 1579, 35 USPQ2d 1116, 1121 (Fed. Cir. 1995); Custom Accessories, Inc. v. Jeffrey-Allan Industries, Inc., 807 F.2d 955, 962, 1 USPQ2d 1196, 1201 (Fed. Cir. 1986); Environmental Designs, Ltd. V. Union Oil Co., 713 F.2d 693, 696, 218 USPQ 865, 868 (Fed. Cir. 1983).

45 UNITED STATES PATENT AND TRADEMARK OFFICE (2001), Chapter 2100, paragraph 2141, pp. 118, citing KSR International, 82 USPQ2d 1385, p. 1397.

46 Kloster Speedsteel AB v. Crucible, Inc., 793 F.2d 1565, 1574 (Fed. Cir. 1986). This timing is the result that the U.S. Patent System follows the "first to invent" approach rather than the "first to file" approach that undertaken in the rest of the world. For the same reason, the rest of the countries will determine the level of ordinary skill in the art is determined at the moment that the invention was filed.
} 
Having resolved the Graham inquiry, the patent examiner will examine whether the claimed invention would have been obvious to a person of ordinary skill in the art. ${ }^{47}$ In doing so, the examiner could use one or more criteria of a non-exhaustive list, including:

“(A) Combining prior art elements according to known methods to yield predictable results;

(B) Simple substitution of one known element for another to obtain predictable results;

(C) Use of known technique to improve similar devices (methods, or products) in the same way;

(D) Applying a known technique to a known device (method, or product) ready for improvement to yield predictable results;

(E) "Obvious to try" - choosing from a finite number of identified, predictable solutions, with a reasonable expectation of success;

(F) Known work in one field of endeavor may prompt variations of it for use in either the same field or a different one based on design incentives or other market forces if the variations are predictable to one of ordinary skill in the art;

(G) Some teaching, suggestion, or motivation in the prior art that would have led one of ordinary skill to modify the prior art reference or to combine prior art reference teachings to arrive at the claimed invention." 48

\subsubsection{Secondary considerations}

As stated in Graham, there are secondary considerations that could be used as indicia of obviousness or nonobviousness. In words of the U.S. Supreme Court:

"[C]ommercial success, long felt but unsolved needs, failure of others, etc., might be utilized to give light to the circumstances surrounding the origin of the subject matter sought to be patented. As indicia of obviousness or nonobviousness, these inquiries may have relevancy" ${ }^{49}$ (emphasis added)

According to MERGES and DUFFY, these kinds of factors have had a major impact within the case law of the Federal Circuit, being considered as "objective indicia" of nonobviousness, occupying in the Circuit's ruling an important role in $\$ 103$ inquiries. ${ }^{50}$ As a matter of fact, in In re Sernaker, ${ }^{51}$ Federal Circuit has come to assert that these considerations, when present, "must always [be considered] in connection with the

\footnotetext{
${ }^{47}$ UNITED STATES PATENT AND TRADEMARK OFFICE (2001), Chapter 2100, paragraph 2141, p. 118.

48 UNITED STATES PATENT AND TRADEMARK OFFICE (2001), Chapter 2100, paragraph 2141, p. 119.

49383 U.S. 1, at pp. 17-18.

${ }^{50}$ Merges and Duffy (2007) p. 661 and 703.

51 See In re Sernaker, 702 F.2d 989, 217 USPQ 1 (Fed. Cir .1983)
} 
determination of obviousness". ${ }^{52}$ What is more, in Stratoflex, ${ }^{53}$ the Federal Circuit came to state the following:

"Indeed, evidence of secondary considerations may often be the most probative and cogent evidence in the record. It may often establish that an invention appearing to have been obvious in light of the prior art was not. It is to be considered as part of all the evidence, not just when the decisionmaker remains in doubt after reviewing the art." 54 (emphasis added)

However, according to the Federal Circuit case law, in order to provide weight to these considerations there must be a nexus between this consideration and the merits of the invention. 55,56

According to MERGES and DUFFY, ${ }^{57}$ after the strong diminishment of the "teaching-suggestion-motivation" test used by the Federal Circuit before KSR International, seems to place more importance upon these considerations. ${ }^{58}$ Furthermore, historical considerations of the development of the claimed invention have increasingly been taking more importance within the Federal Circuit. ${ }^{59}$ However, the reader should note that recent case law (including KSR International) has considered the "commercial success" of the invention as truly secondary consideration. ${ }^{60}$

The MPEP states that in order to consider these consideration, applicants should supply evidence that "may be included in the specification as filed, accompany the application on filing, or be provided in a timely manner at some other point during the prosecution". ${ }^{61}$ Furthermore, "[t]he weight to be given any objective evidence is made on a case-by-case basis. The mere fact that an applicant has presented evidence does not mean that the evidence is dispositive of the issue of obviousness." 62 These can have an important role when considering when the applicant tries to rebut a prima facie case for obviousness. ${ }^{63}$

\footnotetext{
52702 F.2d 989, p. 996.

53 Stratoflex, Inc. v. Aeroquip Corp, 713 F.2d 1530, 218 U.S.P.Q. 871 (Fed. Cir. 1983).

54713 F.2d 1530, pp. 1538-1539

55 In re GPAC, 57 F.3d 1537, 35 U.S.P.Q.2D (Fed. Cir. 1995). See also Hybritech, Inc. v. Monoclonal Antibodies, Inc., 802 F. 2d 1367, 231 U.S.P.Q. 81 (Fed. Cir. 1986).

${ }^{56}$ However, please note that putting too much weight on secondary considerations can lead to a flawed and inefficient approach. See Merges (1988) pp. 803-876; Dreyfuss (1989) pp. 1-77.

57 Merges and DuffyY (2007) pp. 2011-11 Supplement, p. 85.

58 See In Re Sullivan, 498 F.3d 1345 (Fed. Cir. 2007)

${ }^{59}$ See Miniauction, Inc. v. Thompson Corp., 532 F.3d 1318 (Fed. Cir. 2008)

${ }^{60}$ Merges and Duffy (2007) p. 683-684. See also, Ritchie v. Vast Res., Inc., 536 F.3d 1334 (Fed. Cir. 2009)

${ }^{61}$ UNITED STATES PATENT AND TRADEMARK OFFICE (2001), Chapter 2100, paragraph 2141, p. 116.

${ }^{62}$ UNITED STATES PATENT AND TRADEMARK OFFICE (2001), Chapter 2100, paragraph 2141, p. 116.

${ }^{63}$ UNITED STATES PATENT AND TRADEMARK OFFICE (2001), Chapter 2100, paragraph 2141, p. 120.
} 


\subsection{European Patent Law}

Pursuant the European Patent Convention (hereinafter, "EPC"), ${ }^{64}$ the EPO is on charge of granting patents at European level. In order to assess the nonobviousness of a claimed invention ("inventive step" in European terminology), the EPO has drafted the Guidelines for Examination (hereinafter, the "EPO Guidelines") 65 which collects the existing case law at the Patent Office Board of Appeals regarding the "inventive step" requirement set out in article 56 of the EPC. ${ }^{66}$ In this regard, the EPO Guidelines sets out a primary test (the so called "problem-and-solution approach") and a set of secondary considerations. Now we will take a closer look at these.

\subsubsection{The Problem-and-Solution Approach}

The "problem-and-solution approach" is formulated in three steps: "(i) determining the "closest prior art", (ii) establishing the "objective technical problem" to be solved, and (iii) considering whether or not the claimed invention, starting from the closest prior art and the objective technical problem, would have been obvious to the skilled person." 67

(i) First Step: Closest prior art. In order to determine the closest prior art, the EPC determine that the state of the art will be held to comprise "...everything made available to the public ${ }^{68}$ by means of a written or oral description, by use, or in any other way, before the date of filing of the European patent application" ${ }^{69}$ (emphasis added)

According to the EPO the "closest prior art" "... is that which in one single reference discloses the combination of features which constitutes the most promising starting point for an obvious development leading to the invention. In selecting the closest prior art, the first consideration is that it should be directed to a similar purpose or effect as the invention or at least belong to the same or a closely related technical field as the claimed invention". ${ }^{70}$ In general, this will correspond to "... a similar use and requires the minimum of structural and functional modifications to arrive at the claimed invention" ${ }^{71}$

\footnotetext{
${ }^{64}$ Convention on the Grant of European Patents, of 5 October 1973 text as amended by the act revising Article 63 EPC of 17 December 1991 and by decisions of the Administrative Council of the European Patent Organization of 21 December 1978, 13 December 1994, 20 October 1995, 5 December 1996, 10 December 1998 and 27 October 2005 and comprising the provisionally applicable provisions of the act revising the EPC of 29 November 2000.

${ }^{65}$ EUROPEAN PATENT OFFICE (2010).

${ }^{66}$ This provision states, in relevant part that "[a]n invention shall be considered as involving an inventive step if, having regard to the state of the art, it is not obvious to a person skilled in the art." Article 56 of the EPC. ${ }^{67}$ EUROPEAN PATENT OFFICE (2010) Part C, Chapter IV., paragraph 11.5.

68 The reader should note that the phrase "made available to the public" is understood in an extremely broad way. Indeed, it involves any form of public availability (which can be a written description, an oral description, use or any other way). Furthermore, neither the language in which is made available nor the scale by which is made available will be relevant. "The public" can mean even one person. Furthermore, the prior art will consider any information made up in any part of the world. For a more detailed explanation upon this matter see Paterson (2001) pp. 485 et seq.

${ }^{69}$ Article 54(2) of the EPC.

${ }^{70}$ EUROPEAN PATENT OFFICE (2010), Part C, Chapter IV, paragraph 11.5.1.

${ }^{71}$ EUROPEAN PATENT OFFICE (2010), Part C, Chapter IV, paragraph 11.5.1.
} 
In determining the prior art, the examiner will take into account what the applicant acknowledges as such in the patent application (including both description and claims). ${ }^{72}$ (ii) Second Step: Definition of the "objective technical problem" to be solved. According to the EPO Guidelines, the "technical problem means the aim and task of modifying or adapting the closest prior art to provide the technical effects that the invention provides over the closest prior art." 73, 74

In order to identify the technical problem, the examiner has to study the patent application, the closest prior art and the difference between both of them. By doing that vis-á-vis comparison, the examiner will determine the distinguishing features of the claimed invention and the "technical problem" that the claimed invention tried to solve. ${ }^{75}$

According to the EPO Guidelines, the patent examiner is who defines the technical problem. That is why the EPO Guidelines makes clear that the technical problem "may not be what the applicant presented as "the problem" in his application". ${ }^{76}$ If that is the case, the examiner will reformulate the technical problem. This is likely to happen when, during the prosecution procedure, it appears other prior art that the applicant was unaware of at the moment of the application. ${ }^{77}$

(iii) Third Step: Assessment of the Inventive Step. Having identified the technical problem, the EPO Guidelines asks whether the claimed invention is "obvious" for a "person skilled in the art" (hereinafter, the "PHOSITA"). In order to do so, it first defines the PHOSITA. According to the PHOSITA Guidelines, the PHOSITA has the following features:

- The PHOSITA is defined by the technical problem involved. ${ }^{78}$

- The PHOSITA has to be considered as a practitioner in the relevant field, who "[possesses] average knowledge and ability and is aware of what was common general knowledge in the art at the relevant date" ${ }^{79}$

- The PHOSITA is supposed to have access "to everything in the "state of the art", in particular the documents cited in the search report, and to have had at his disposal the normal means and capacity for routine work and experimentation". ${ }^{80}$

\footnotetext{
72 EUROPEAN PATENT OFFICE (2010), Part C, Chapter IV, paragraph 11.5.1.

73 EUROPEAN PATENT OFFICE (2010), Part C, Chapter IV, paragraph 11.5.2.

74 According to the EPO Guidelines, the expression "technical problem" should be interpreted broadly. This expression "...does not necessarily imply that the technical solution is a technical improvement over the prior art. Thus the problem could be simply to seek an alternative to a known device or process which provides the same or similar effects or is more cost-effective." EUROPEAN PATENT OFFICE (2010), Part C, Chapter IV., paragraph 11.5.2.

75 EUROPEAN PATENT OFFICE (2010), Part C, Chapter IV., paragraph 11.5.2.

76 EUROPEAN PATENT OFFICE (2010), Part C, Chapter IV., paragraph 11.5.2.

77 EUROPEAN PATENT OFFICE (2010), Part C, Chapter IV., paragraph 11.5.2.

78 Case T-422/93, JALON / Luminescent security fibres O.J. EPO 1997, p. 24; [1999] E.P.O.R. 533. Also cited in Paterson (2001) p. 545.

${ }^{79}$ EUROPEAN PATENT OFFICE (2010), Part C, Chapter IV., paragraph 11.3.

${ }^{80}$ EUROPEAN PATENT OFFICE (2010), Part C, Chapter IV., paragraph 11.3.
} 
- The PHOSITA "is involved in constant development in his technical field" and is expected "to look for suggestions in neighbouring and general technical fields [...] or even in remote technical fields, if prompted to do so". ${ }^{81,82}$

Furthermore, it has to be noted that the EPO case law considers that the PHOSITA can be a team of specialists. ${ }^{83}$

The core question that the EPO faces when assessing the inventive step in an invention is "... whether there is any teaching in the prior art as a whole that would (not simply could, but would) have prompted the skilled person, faced with the objective technical problem, to modify or adapt the closest prior art while taking account of that teaching, thereby arriving at something falling within the terms of the claims, and thus achieving what the invention achieves" 84 . In this regard, an invention would be "obvious" if it "does not go beyond the normal progress of technology but merely follows plainly or logically from the prior art". 85

In the context of examining the obviousness of the claimed invention, the combination of different teaching coming from the state of the art, including the "closest prior art", the invention could be considered as lacking from inventive step. ${ }^{86}$ Nevertheless, the EPO Guidelines makes clear that "the fact that more than one disclosure must be combined with the closest prior art in order to arrive at a combination of features may be a sign of the presence of an inventive step, e.g. if the claimed invention is not a mere aggregation of features". ${ }^{87}$ In order to assess whether the combination of distinct disclosures leads to a mere aggregation of features, the EPO Guidelines proposes three criteria: (i) the likelihood that the PHOSITA, in trying to solve the "objective technical problem", would combine them; (ii) whether the different disclosures comes from "similar, neighbouring or remote technical fields" and (iii) whether there is a "reasonable basis" to expect that the PHOSITA will associate the different disclosures. ${ }^{88}$

One of the main criticisms against the "problem-and-solution approach" is that it can generate hindsight bias. As PATERSON notes, this approach "relies on the results of a search made with actual knowledge of the claimed invention, and therefore is inherently based on hindsight". ${ }^{89}$ For such reason, the PTO Board of Appeals' case law has been careful to note that the examination of this requirement is assessed "in the light of the

\footnotetext{
${ }^{81}$ EUROPEAN PATENT OFFICE (2010), Part C, Chapter IV., paragraph 11.3.

${ }^{82}$ However, the knowledge of the PHOSITA "does not include that of a specialist in the different field to which the proposed solution belongs if the closest prior art gives bio indication that the solution is to be sought in this other technical field" Case T-422/93, JALON / Luminescent security fibres O.J. EPO 1997, p. 24; [1999] E.P.O.R. 533.

83 See, for instance, Case T-164/92, BOSCH / Electronic computer components, OJ 1995, p. 305; Case T-141/87, BOSCH / Diagnostic test system for motor vehicles [1996] E.P.O.R. 570; Case T-60/89 HARVARD / Fusionproteins, OJ 1992, p. 268.

${ }^{84}$ EUROPEAN PATENT OFFICE (2010), Part C, Chapter IV., paragraph 11.5.3.

${ }^{85}$ EUROPEAN PATENT OFFICE (2010), Part C, Chapter IV., paragraph 11.4.

${ }^{86}$ EUROPEAN PATENT OFFICE (2010), Part C, Chapter IV., paragraph 11.6.

${ }^{87}$ EUROPEAN PATENT OFFICE (2010), Part C, Chapter IV., paragraph 11.6.

${ }^{88}$ EUROPEAN PATENT OFFICE (2010), Part C, Chapter IV., paragraph 11.6.

${ }^{89}$ PATERSON (2001) p. 536.
} 
state of the art and from the viewpoint of the closest prior art (looking forward) and not from that of the invention (looking backward)" ${ }^{90}$. A similar warning can be found in the EPO Guidelines. ${ }^{91}$

\subsubsection{Other means to assess the obviousness of an invention}

The PTO recognizes that the "problem-and-solution approach" is one possible route for the assessment of the obviousness of the invention; is not a sine qua non route. ${ }^{92}$ Still there are other proxies that can be used. Now we pass to examine them.

If the solution of the claimed invention produces an unexpected technical effect or progress this can be considered as an indicia of nonobviousness. ${ }^{93}$ However, the CPO disregards this approach if it would already have been obvious for a skilled person to arrive at something falling within the terms of a claim, for example due to a lack of alternatives thereby creating a "one-way street" situation, the unexpected effect is merely a bonus effect which does not confer inventiveness on the claimed subject-matter" ${ }^{94}$

Another proxy used by the PTO is the long felt need of the invention. In this regard, the EPO Guidelines states that " $[\mathrm{w}]$ here the invention solves a technical problem which workers in the art have been attempting to solve for a long time, or otherwise fulfils a long-felt need, this may be regarded as an indication of inventive step." 95 As insinuated by TRITTON et al., this approach can be useful to overcome hindsight bias. ${ }^{96}$

According to PATERSON, this factor tends to be generally used "as a corroboration of a finding of inventive step which has already been deduced on the basis of other reasoning" ${ }^{97}$ Nevertheless, according to the EPO Guidelines they have long felt proxy shall be particularly important if is coupled with the commercial success of the claimed invention. ${ }^{98}$

90 Case T-181/82, CIBA-GEIGY / Spiro Compounds, O.J. EPO 1984, p. 401. Also cited in Paterson (2001) p. 543.

${ }^{91}$ Indeed, the EPO Guidelines warn examiners that "It should be remembered that an invention which at first sight appears obvious might in fact involve an inventive step. Once a new idea has been formulated, it can often be shown theoretically how it might be arrived at, starting from something known, by a series of apparently easy steps. The examiner should be wary of ex post facto analysis of this kind. When combining documents cited in the search report, he should always bear in mind that the documents produced in the search have, of necessity, been obtained with foreknowledge of what matter constitutes the alleged invention." EUROPEAN PATENT OFFICE (2010), Part C, Chapter IV., paragraph 11.8.

92 Case T-465/92, ALCAN / Aluminum alloys, O.J. EPO 1996, p. 32; [1995] E.P.O.R. 501. Also cited in Paterson (2001) p. 536.

93 See, inter alia, Case T-181/82, CIBA-GEIGY / Spiro Compounds, O.J. EPO 1984, p. 401; Case T-22/82, BASF / Bis-expoxy ethers, OJ EPO 1982, p. 341; Case T-386/89, GKN SANKEY / Tractor Weels [1996] E.P.O.R. 37. For further comment of the existing case law see Paterson (2001) p. 553 et seq. and Tritton (2008) p. 107 et seq.

${ }^{94}$ EUROPEAN PATENT OFFICE (2010), Part C, Chapter IV., paragraph 11.10.2.

${ }^{95}$ EUROPEAN PATENT OFFICE (2010), Part C, Chapter IV., paragraph 11.10.3.

${ }^{96}$ Tritton (2008) p. 107

${ }^{97}$ Paterson (2001) p. 561.

${ }^{98}$ EUROPEAN PATENT OFFICE (2010), Part C, Chapter IV., paragraph 11.10.3. 
FERNÁNDEZ, Fernando — "The non-obviousness requirement in the chilean patent law: A critical assessment"

Other indicatives of nonobviousness not considered in the PTO Guidelines but used by the case law is the existence of prejudice of the prior art against the technical solution provided by the invention. ${ }^{99}$

As we can see, the EPO provide less weight to these considerations as it can be found within the U.S. Federal Circuit Case Law. However, both regimes consider these factors in order to assess the obviousness of an invention.

Both MPEP and EPO Guidelines have been very influential in order to guide the criterion used by the Chilean Patent Office. Now we shall focus our attention in the nonobviousness standard applied in Chile.

\section{THE "NON-OBVIOUSNESS" REQUIREMENT IN THE CHILEAN LEGISLATION. PRELIMINARY BACKGROUND}

Until January 25, 1991, the Chilean legislation did not contain a "nonobviousness" requirement. ${ }^{100}$ Article 35 of the IPA establishes this standard. ${ }^{101}$ This provision states the following:

"Article 35.- An invention shall be regarded as involving an inventive step if it is neither obvious to a person of average skill in the art nor obviously derived from the state of the art." 102

As we shall see, this provision has been subject to analysis and interpretation by the CPO. Yet, before discussing this issue, it is important to provide a brief notice of procedural matters.

The analysis over an invention under the light of the "nonobviousness" standard can operate in two instances. The first of them is in the prosecution process before CPO.

A second instance is when somebody challenges the validity of the patent. ${ }^{103}$ This circumstance opens a validity trial in which the Director of the Instituto Nacional de Propiedad Industrial (hereinafter, "INAPI") operates as a judge of first instance. In this

\footnotetext{
${ }_{99}$ Case T-18/81, SOLVAY / Olefine polymers, O.J. EPO 1985, p. 166; Case T-261/87, TILTOTT / Carminative preparation [2003] E.P.O.R. 18.

${ }^{100}$ Indeed, prior this date, the Decree Law No. 958 of 1931, which governed the patent system until that date only required inventions to be novel and have industrial utility. See articles 4, 5 and 6 of Decree Law No. 958 of 1931 establishing the consolidated text of the Industrial Property Act, published in the Official Gazette on July 27, 1931. Spanish version available on line at: <http://bit.ly/fCgmCh> [last visit: February 17, 2011]

101 Law No. 19.039 (of January 24, 1991) establishing Rules Applicable to Industrial Privileges and the Protection of Industrial Property Rights, in the Official Gazette on January 25, 1991. English version available on line at: <http://bit.ly/iG79je> [last visit: February 17, 2011]

102 The translation into English is mine. The Spanish version of this provision states the following: "Artículo 35.- Se considera que una invención tiene nivel inventivo, si para una persona normalmente versada en la materia técnica correspondiente, ella no resulta obvia ni se habría derivado de manera evidente del estado de la técnica."

${ }^{103}$ According to article 5 of the Industrial Property Right, any person who shows a legitimate affected interest is entitled to trigger the start of this procedure. As a general matter, this procedure is initiated as a counterclaim in infringement trials.
} 
event, the Director of INAPI heavily relies upon the criterion of the judgement that he receives from an expert in the relevant area who works in his staff. Indeed, as a general matter, the Director of INAPI will resolve the validity issue in accordance with this opinion. Therefore, it is proper to say that the de facto judge in a validity claim on the first instance will be the expert appointed to analyse the scientific information provided by the parties. Therefore, more than a legal trial, this procedure becomes an exchange of expert opinions given by the parties. The second instance is held by the Industrial Property Tribunal (hereinafter, the "TPI"), which will resolve the issue as an appellate tribunal. Still, is important to note that the TPI is not obliged to follow the CPO Guidelines in order to assess whether an invention is obvious.

Having summarised the procedural context in which an invention is subject to a nonobviousness analysis, we can now analyse the relevant criteria used in the CPO's Nonobviousness Guidelines.

\section{THE CPO GUIDELINES FOR ASSESSING THE NON-OBVIOUSNESS REQUIREMENT}

Before 2009, the CPO did not have any guidelines that provided uniform principles for analyzing an invention under the nonobviousness standard. Consequently, analysis of this requirement tended to rely upon the understanding of the patent examiner in a specific case. Yet, in May 2009, the INAPI published the first guidelines for patent examiners in order to asses whether an invention is or not obvious. ${ }^{104}$

As stated in the main CPO's Nonobviousness Guidelines, this shall apply not only in the patent-prosecution process, but also in the case where an expert submits his judgment to the Director of INAPI in an invalidation process. ${ }^{105}$ Therefore, this Guideline goes beyond the administrative process to become a key factor in the judicial process of first instance.

\subsection{The "PROBLEM-AND-SOLUTION APPROACH"}

According to the same CPO's Nonobviousness Guidelines, ${ }^{106}$ the nonobviousness assessment relies heavily on the "problem-and-solution approach" proposed by then EPO Guidelines with some minor adjustments of the USTPO's MPEP.

Accordingly, it uses the three-step test that we where able to discuss when we discussed the EPO Guidelines. Still, before proposing its standard, the CPO's Nonobviousness Guidelines specify what understand by "relevant art" and the PHOSITA:

104 INSTITUTO NACIONAL DE PROPIEDAD INDUSTRIAL (2009). (Hereinafter, the "CPO's Nonobviousness Guidelines")

105 INSTITUTO NACIONAL DE PROPIEDAD INDUSTRIAL (2009) p. 3.

106 INSTITUTO NACIONAL DE PROPIEDAD INDUSTRIAL (2009) p. 4. 


\subsubsection{Definition of the relevant art}

According to article 33 of the CPA, the prior art will be "all the technical knowledge which has been made public prior to the patent application filing date in Chile or the priority date claimed [in the case of international prior applications], by means of an oral or written description, sale, marketing, use, or any other means of dissemination or information, anywhere in the world".

According to the CPO's Novelty Guidelines, the CPO makes clear that the prior art will include any geographical location, language and form that are made public. Furthermore, the information will be considered as having "been made public" if it was possible to the public to know the existence of it, provided that there was no confidentiality obligation for the people who accessed that information. ${ }^{107}$

\subsubsection{The attributes the person skilled in the art}

According to the CPO's Nonobviousness Guidelines, the PHOSITA has the following qualities:

(i) As a hypothetical person, it to be considered as different from both inventor and examiner.

(ii) The PHOSITA is supposed to know all the previous art until the date of the filing of the application.

(iii) It has the professional skills of a professional in the relevant art.

(iv) The PHOSITA is person has an ordinary level of creativity. ${ }^{108}$

\subsubsection{The stages of analysis the "problem-and-solution approach"}

Having defined the prior art and the PHOSITA, the CPO's Nonobviousness Guidelines use a three-step test similar to the EPO's "problem-and-solution approach":

(a) Stage I: Determination of the closes state of the art. Under this stage, examiners are required to define the "closest state of the art". The Guidelines does not provide too much guidance in this respect. It only states that it will be the document with more number of characteristics and technical effects in common with the claimed invention. ${ }^{109}$

Although the "previous art" can be any oral or written description, sale, marketing, use or any other means of dissemination or information, anywhere in the world, the CPO's Nonobviousness Guidelines will only consider only documents as the "closest prior art". This inconsistency is rather puzzling. The CPO's Nonobviousness Guidelines do not give any particular reason for narrowing the scope of analysis of the examiner.

Since the "closest prior art" is a key determinant in a "problem-and-solution approach" test, this could lead to the absurd result: we could have device that is identical to the invention but that is taken aside as that the "closest previous art" for the nonobviousness analysis for the mere fact that its characteristics were not documented.

\footnotetext{
${ }^{107}$ INSTITUTO NACIONAL DE PROPIEDAD INDUSTRIAL (2009b).

108 INSTITUTO NACIONAL DE PROPIEDAD INDUSTRIAL (2009) p. 5.

109 INSTITUTO NACIONAL DE PROPIEDAD INDUSTRIAL (2009), paragraph 3.1.1., p. 7.
} 
Furthermore, despite the fact that the CPO's Nonobviousness Guidelines claims to follow EPO Guidelines in this regard, it seems puzzling to figure out why the former did not follow the approach taken by the latter. ${ }^{110}$

(b) Stage II: Determination of the differences between the closest art and the claimed invention. To do so, the examiner has to consider "the effect or result" that differentiates the claimed invention and the closest art. The effects of the claimed invention will be taken from the claims in its overall and in an objective way (i.e., taking aside what are the effects that the inventor claims that are solved with the invention). ${ }^{11}$

In this stage of analysis another puzzling situation arises. Indeed, according to the CPO's Nonobviousness Guidelines, the examiner has to focus his analysis only in the claims of the patent, taking aside the specifications. The inexplicable approach taken by the CPO's Nonobviousness Guidelines entails the risk that the examiner could undertake a short-sighted analysis and ill-defined interpretation of the claimed invention, impeding a more accurate comparison with closest previous art. Furthermore, this clearly departs from the approach taken by the MPEP and the CPO Guidelines (both consider both disclosure and claims for this analysis).

Another limitation within this part of the examination is the fact that the CPO's Nonobviousness Guidelines seems to consider that no comparison is needed between the claimed invention and other reasonably related areas of the relevant state of the art. Again, this limits the scope of examination of the claimed invention in a way that is neither suggested by the MPEP nor by the EPO Guidelines.

What is more, the CPO's Nonobviousness Guidelines does not provide too much guidance about on how to figure out which is the objective technical problem and which are the reasons that the examiner would have to claim to depart from what the patent applicant claims to be the technical problem that his invention actually solves. This circumstance provides little predictability for the innovator that is willing to disclose his invention instead of keeping it in secret.

(c) Stage III: Determination of the differences between the closest art and the claimed invention. In this stage, the examiner has to answer whether the PHOSITA, knowing all the previous art, and without employing any inventive skill, would recognized the problem solved by the claimed invention.

The crucial point here, is whether the state of the art would have induced the PHOSITA to adapt, combine or modify the closest art an reach to the same results of the claimed invention.

(i) If any of the previous art solves the same objective technical problem, then the invention should be held as nonobvious. ${ }^{112}$

(ii) However, if the examiner does find that the previous art resolves the objective technical problem of the claimed invention, the examiner has to ask whether there is any

110 Indeed, the EPO Guidelines do not make the distinction made by the CPO's Nonobviousness Guidelines.

See EPO Guidelines, Part C, Chapter IV, paragraphs 11.5.1. and 11.5.2.

${ }^{111}$ INSTITUTO NACIONAL DE PROPIEDAD INDUSTRIAL (2009), paragraph 3.1.2., pp. 7-8.

112 INSTITUTO NACIONAL DE PROPIEDAD INDUSTRIAL (2009), paragraph 3.1.3., pp. 9-10. 
teaching, suggestion or motivation in the state of the art that, in the overall, would have induced the PHOSITA to adapt, modify or combine the closest state of the art in order to reach the same technical effects of the claimed invention. In the case that teaching, suggestion or motivation exist, then the invention will be held obvious. ${ }^{113}$

Part (ii) of this examination seems to be a limit to the examiner into applying the "teaching-suggestion-motivation" test used by the Federal Circuit before KSR International. ${ }^{114}$ This contrast sharply with both the MPEP and the EPO Guidelines which tend to provide a set of different tests to apply with the aim of allowing the examiner to have enough flexibilities to test the claimed invention from different viewpoints at the same time.

\subsection{SECONDARY CONSIDERATIONS}

As we were able to see before, the U.S. and the European patent law weight these considerations in a rather different manner. Indeed, the Federal Circuit case law gives a much stronger weight to these considerations that their European counterparts. But still both laws consider these factors as relevant proxies to a nonobviousness analysis.

In this regard, the CPO's Nonobviousness Guidelines dramatically departs from the EPO Guidelines and the MPEP by giving no value to these considerations.

This choice is insensible to the economic underpinnings of the nonobviousness requirement discussed above. Considerations such as the long felt need, the unexpected technical effect or progress, the existence of prejudices in prior art and the historical considerations of the development of the claimed invention would be extremely useful to see whether the resources in $\mathrm{R} \& \mathrm{D}$ of the claimed invention where spent in the quest of searching for something more than mere incremental innovations. ${ }^{115}$ All these considerations, indeed, would provide the patent examiner and courts a much broader picture about the invention that is subject of analysis.

Similarly, the commercial success with a clear nexus with the inventive qualities of the claimed inventions would be useful tool to take aside low-contribution discoveries (therefore, minimizing rent seeking behaviours) and analyse whether the invention was unlikely to be developed without a patent.

\section{CONCLUDING REMARKS}

The nonobviousness requirement is a rather difficult requirement to asses with accuracy. With a good deal or reason, Judge Learned Hand once famously lamented about the nonobviousness requirement stating that it is "as fugitive, impalpable, wayward, and vague a phantom as exists in the whole paraphernalia of legal concepts." 116 Furthermore, if we contrast the different approaches taken by the U.S., Europe and Chile, the standards

\footnotetext{
113 INSTITUTO NACIONAL DE PROPIEDAD INDUSTRIAL (2009), paragraph 3.1.3., pp. 9-10.

${ }^{114}$ To be sure, the reader should be aware that this test is still used Federal Circuit. Nevertheless, as Merges and Duffy notes, in a rather limited manner. See Merges and Duffy (2007) 2010-11 Supplement, p. 81.

115 In this regard, see Duffy (2008) pp. 343-374; Miller (2008) pp. 579-598.

116 Harries v. Air King Prod. Co., 183 F.2d 158, p. 162 (2d Cir. 1950).
} 
of examination of this requirement are rather different, posing important barriers for the harmonization of patent laws around the globe. ${ }^{117}$

However, the advantages that this standard provide in order to draw a line to protect patent-worthy innovations seems to be fundamental. In that regard, the advance made by the CPO in trying to draw such line is commendable if we consider that this is the first attempt made by a Latin American Patent Office. Yet, as this paper has shown, the CPO's Nonobviousness Guidelines should be subject to an extensive review since it contains a series of inconsistencies and limitations that excessively narrow the scope of analysis that the patent examiner can use. Furthermore, there seems to be a need to discuss the inclusion of secondary factors to assess the nonobviousness requirement in order to provide further elements of examination of patent applications.

I hope that this critical assessment of CPO's Nonobviousness Guidelines could become a first step in such direction.

\section{BIBLIOGRAPHY}

'The disclosure function of the Patent System (or lack thereof)', Harvard Law Review, Vol. 118, issue 6, 2005, pp. 2007-2028.

Barton, John H (2003): 'Non-Obviousness', IDEA, Vol. 43, No. 3, pp. 475-508.

Cornish, William and Llewelyn, David (2003): "Intellectual Property: Patents, Copyright, Trade Marks and Allied Rights" (5 ${ }^{\text {th }}$ edition, Sweet \& Maxwell, London).

Cotropia, Christopher y GIBSON, James (2010): 'The Upside of Intellectual Property's

Downside', UCLA Law Review, Vol. 57, No. 4, pp. 921-982.

DAm, Kenneth W. (1994): 'The Economic Underpinnings of Patent Law', The Journal of Legal Studies, Vol. 23, No. 1, pp. 247-271.

Devlin, Alan (2010): 'The Misunderstood Function of Disclosure in Patent Law', Harvard Journal Fof Law \& Technology, Vol. 23, No. 2, pp. 1-45.

Durie, Daralyn and Lemley, Mark A. (2008): 'A Realist Approach to the Obviousness of Inventions', William and Mary Law Review, Vol. 50, No. 3, pp. 989-1020.

Dreyfuss, Rochelle C. (1989): 'The Federal Circuit: A Case Study in Specialized Courts', New York University Law Review, Vol. 64, No. 1, pp. 1-77.

Duffy, John (2008): 'Timing Approach to Patentability', Lewis \& Clark Law Review, Vol. 12, Issue 2, pp. 343-374.

Esienberg, Rebecca (2004): 'Obvious to whom? Evaluating inventions from the perspective of PHOSITA', Berkeley Technology Law Journal, Vol. 19, pp. 885-906.

Franzosi, Mario (2003): 'Non-Obviousness', The Journal of World Intellectual Property, Vol. 6, Issue 2, pp. 233-250.

Ghidini, Gustavo (2006): "Intellectual Property and Competition Law: The innovation nexus" (Edward Elgar Publishing, Cheltenham and Northampton).

117 See Reichman and Dreyfuss (1989) p. 99. 
FERNÁNDEZ, Fernando — "The non-obviousness requirement in the chilean patent law: A critical assessment"

Judd, Kenneth L., Schmedders, Karl, Yeltekin, Sevin (2010): 'Optimal Rules for Patent Races', p. 30. Available at SSRN: <http://ssrn.com/abstract=1797891> [visited: May 11, 2011]

Kiтch, Edmund W. (1966): 'Graham v. John Deere Co.: New Standard for Patents', Supreme Court Review, Vol. 1966, pp. 293-346.

LANDES, William and POSNER, Richard (2003): "The Economic Structure of Intellectual Property Law" (The Belknap Press of Harvard University Press, Cambridge - London).

Machlup, Fritz and PENROSE, Edith (1950): 'The Patent Controversy in the Nineteenth Century', The Journal of Economic History, Vol. 10, No. 1, p. 1-29.

Mazzoleni, Roberto and NELSON, Richard (1998): 'Economic Theories about the Benefits and Costs of Patents', Journal of Economic Issues, Vol. 32, issue 4, pp. 10311052

Merges, Robert P. (1988): “Commercial Success and Patent Standards: Economic Perspectives on Innovation”. California Law Review, Vol. 76, issue 4, pp. 803-876.

Merges, Robert P. (1992): 'Uncertainty and the Standard of Patentability', High Technology Law Journal, No. 7.

Merges, Robert P. and Duffy, John F. (2007): "Patent Law and Policy: Cases and Materials" ( $4^{\text {th }}$ edition, LexisNexis).

Miller, Joseph S. (2008): 'Level of Skill and Long-Felt Need: Notes on a Forgotten Future', Lewis \& Clark Law Review, Vol. 12, Issue 2, pp. 579-598.

Muir, Ian, Brandi-Dohrn, Matthias and Gruber, Stephan (2002): "European Patent Law. Law and Procedure under the EPC and PCT" (2 $2^{\text {nd }}$ edition, Oxford University Press, Oxford - New York).

ORGANIZATION FOR ECONOMIC CO-OPERATION AND DEVELOPMENT (2008)1: "Innovation Strategy: Harnessing the Power of Innovation", SG/INNOV, February 15, 2008.

Pagenberg, Jochen (1978): 'The Evaluation of the 'Inventive Step' in the European Patent System - More Objective Standards Needed', International Review of Industrial Property (IIC), Vol. 9, No. 2, pp. 121-152.

Paterson, Gerald (2001): "The European Patent System: The Law and Practice of the European Patent Convention" (2 $2^{\text {nd }}$ edition, Sweet and Maxwell, London).

Posner, Richard (2007): "Economic Analysis of Law" (7 $7^{\text {th }}$ edition, Aspen Publishers, New York).

Schumpeter, Joseph (1954): "Capitalism, socialism and democracy" (4th ed, Allen \& Unwin, London).

Solow, Robert (1956): "A Contribution to the Theory of Economic Growth," The Quarterly Journal of Economics, Vol. 70, No. 1., pp. 65-94.

Solow, Robert (1957): "Technical Change and the Aggregate Production Function," The Review of Economics and Statistics, Vol. 3, No. 3, pp. 312-320.

Szabo, G.S.A (1986): 'The problem and solution approach to the inventive step', European Intellectual Property Review, Vol. 8, No. 10, pp. 293-303.

Stiglitz, Joseph E. (2007): 'Economic Foundations of Intellectual Property Rights', Duke Law Review, Vol. 57, No. 6, pp. 1693-1724. 
Tritton, Guy, et al (2008): "Intellectual Property in Europe" (3 $3^{\text {rd }}$ edition, Sweet and Maxwell, London).

Mojıвi, Ali (2010): 'An Empirical Study of the Effect of KSR v. Teleflex on the Federal Circuit's Patent Validity Jurisprudence', Albany Law Journal of Science and Technology, Vol. 20, No. 3, pp. 559-596.

Simic, Emer (2009): 'The TSM Test Is Dead! Long Live The TSM Test! The Aftermath Of KSR, What Was All The Fuss About?', AIPLA Quarterly Journal, Vol. 37, No. 2, pp. 227-256.

\section{ACTS, INTERNATIONAL TREATIES, OTHER REGULATIONS AND GUIDELINES}

Decree Law No. 958 of 1931 establishing the consolidated text of the Industrial Property Act, published in the Official Gazette on July 27, 1931.

Agreement on Trade-Related Aspects of Intellectual Property Rights, Apr. 15, 1994, Marrakesh Agreement Establishing the World Trade Organization, Annex 1C, 1869 U.N.T.S. 299 (1994).

European Community, recital 5 of the European Commission Regulation (EC) No 772/2004 of 27 April 2004 on the application of Article 81(3) of the Treaty to categories of technology transfer agreements, L 123 O.J., 27.4.2004. , pp. 11-17.

Guidelines on the application of Article 81 of the EC Treaty to technology transfer agreements. C 101 O.J., 27.4.2004, pp. 2-42.

Law No. 19.039 (of January 24, 1991) establishing Rules Applicable to Industrial Privileges and the Protection of Industrial Property Rights, in the Official Gazette on January 25, 1991.

Ministry of the Economy Law-Ranking Decree No. 3 of 20 June 2006 establishing the consolidated, coordinated and systematized text of Law No. 19.039 on Industrial Property, published in the Official Gazette on June 26, 2006.

Convention on the Grant of European Patents, of 5 October 1973 text as amended by the act revising Article 63 EPC of 17 December 1991 and by decisions of the Administrative Council of the European Patent Organization of 21 December 1978, 13 December 1994, 20 October 1995, 5 December 1996, 10 December 1998 and 27 October 2005 and comprising the provisionally applicable provisions of the act revising the EPC of 29 November 2000.

EUROPEAN PATENT OFFICE (2010): Guidelines for Examination in the European Patent Office, revised on April 2010. Available on line: <http://www.epo.org/lawpractice/legal-texts/guidelines.html> [Visited: May 11, 2011].

INSTITUTO NACIONAL DE PROPIEDAD INDUSTRIAL (2009): Altura Inventiva, May 2009, Spanish version available online at: <http://bit.ly/eISLLH > [Visited on February 17, 2011].

INSTITUTO NACIONAL DE PROPIEDAD INDUSTRIAL (2009b): Novedad, May 2009, p. 3. Avaliable on line: <http://www.inapi.cl/images/stories/Documentos/ patentes/Novedad-mayo2009.pdf> [visited: May 15, 2011] 
FERNÁNDEZ, Fernando " "The non-obviousness requirement in the chilean patent law: A critical assessment"

UNITED STATES PATENT AND TRADEMARK OFFICE (2001): Manual of Patent Examining Procedure (MPEP), Eighth Edition, August 2001, Latest Revision July 2010. Available on line: <http://www.uspto.gov/web/offices/pac/mpep/mpep.htm> [Visited: May 11, 2011].

\section{CASES}

\section{U.S. Case Law}

Custom Accessories, Inc. v. Jeffrey-Allan Industries, Inc., 807 F.2d 955, 962, 1 USPQ2d 1196, 1201 (Fed. Cir. 1986).

Environmental Designs, Ltd. V. Union Oil Co., 713 F.2d 693, 696, 218 USPQ 865, 868 (Fed. Cir. 1983).

Graham v. John Deere Co., 383 U.S. 1; 148 USPQ 459 (1966).

Harries v. Air King Prod. Co., 183 F.2d 158 (2d Cir. 1950).

Hybritech, Inc. v. Monoclonal Antibodies, Inc., 802 F. 2d 1367, 231 U.S.P.Q. 81 (Fed. Cir. 1986).

In re Bass, 474 F.2d 1276 (C.C.P.A. 1973).

In re GPAC, 57 F.3d 1537, 35 U.S.P.Q.2D (Fed. Cir. 1995).

In re Sernaker, 702 F.2d 989, 217 USPQ 1 (Fed. Cir .1983).

In Re Sullivan, 498 F.3d 1345 (Fed. Cir. 2007).

KSR International Co. v. Telflex Inc., 550 U.S. 398 (2007); 82 USPQ2d 1385 (2007);

2007 U.S. LEXIS 4745 (April 30, 2007).

Miniauction, Inc. v. Thompson Corp., 532 F.3d 1318 (Fed. Cir. 2008).

Ritchie v. Vast Res., Inc., 536 F.3d 1334 (Fed. Cir. 2009).

Stratoflex, Inc. v. Aeroquip Corp, 713 F.2d 1530, 218 U.S.P.Q. 871 (Fed. Cir. 1983).

Winner International Royalty Corp. v. Ching-Rong Wang, 202 F.3d 1340, 53 U.S.P.Q.2d 1580 (Fed. Cir., 2000).

Kloster Speedsteel AB v. Crucible, Inc., 793 F.2d 1565, 1574 (Fed. Cir. 1986).

European Case Law

Case T-422/93, JALON / Luminiscent security fibres O.J. EPO 1997, p. 24; [1999] E.P.O.R. 533.

Case T-164/92, BOSCH / Electronic computer components, OJ 5/1995, p. 305.

Case T-141/87, BOSCH / Diagnostic test system for motor vehicles [1996] E.P.O.R. 570.

Case T-181/82, CIBA-GEIGY/Spiro Compounds, O.J. EPO 1984, p. 401.

Case T-465/92, ALCAN / Aluminum alloys, O.J. EPO 1996, p. 32; [1995] E.P.O.R. 501.

Case T-22/82, BASF / Bis-expoxy ethers, OJ EPO 1982, p. 341.

Case T-386/89, GKN SANKEY / Tractor Weels [1996] E.P.O.R. 37.

Case T-18/81, SOLVAY / Olefine polymers, O.J. EPO 1985, p. 166.

Case T-261/87, TILTOTT / Carminative preparation [2003] E.P.O.R. 18. 